\title{
THEORETICAL AND ECONOMIC PREREQUISITES FOR THE DEVELOPMENT OF REGIONAL INDUSTRIAL CLUSTERS IN THE ECONOMY OF THE REPUBLIC OF UZBEKISTAN
}

\author{
Khankeldieva Guzal Sherovna \\ Professor of the Ferghana Politechnical Institute, Dsc.150100, Ferghana street 86, Ferghana city, \\ Uzbekistan
}

Article DOI: https://doi.org/10.36713/epra4855

\begin{abstract}
The article focuses on the theoretical foundations of the development of regional industrial clusters, as well as identifies economic aspects of improving the activities of regional clusters in strategically important sectors of the economy of the Republic of Uzbekistan. As the examples of successful clusters show, the inclusion of medium and small enterprises in them is necessary to increase the flexibility and speed of the cluster's response to external changes, thereby increasing its competitiveness. The development of the innovation environment and institutions of network interaction is also a mandatory step in the formation of clusters.
\end{abstract}

KEY WORDS: cluster, cluster classification, industry, regional cluster, modernization, synergy effect, innovation, innovation cluster, production efficiency, investment resources, public-private partnership.

\section{INTRODUCTION}

At the present stage of industrial development in the Republic of Uzbekistan, an important role is played by the development of new forms of integration associations between enterprises of the dominant sectors of the economy. Innovative regional clusters are one of the promising forms of integration associations that contribute to the accelerated modernization of the region's economy. In the conditions of modernization of economic relations, the content of such forms of integration is expanding, which is the reason for new scientific research in this direction.

Currently, the concept of "regional cluster" is one of the most widely discussed in the economic literature abroad. In terms of sustainable development of economy of the Republic of Uzbekistan, the task is to find effective organizational and economic development of key industries in the region.

The essence of the cluster approach is that clusters represent geographically localized chains of independent organizations with intensive vertical and horizontal connections, which gives a synergistic effect [1].

\section{LITERATURE REVIEW}

The American economist M. porter made a significant contribution to the development of cluster theory. He considered a cluster as a group of geographically adjacent interconnected companies and related organizations operating in a certain area, characterized by common activities and complementary to each other [2].

The concept of "cluster" was introduced to Economics by Professor M. porter of the Harvard business school, who defined a cluster as a set of geographically concentrated interconnected enterprises, specialized suppliers, financial and consulting enterprises, research and educational organizations that compete.

The definition of M.V.Bespalov is considered the most popular among authors in the field of regional studies. According to its definition, a cluster is a Union of entrepreneurs whose members are linked by agreements on strategic interaction.

E.V.Kurkudinova considers the cluster as [4]:

- Regionally limited forms of economic activity within related sectors; 


\section{SJIF Impact Factor: 7.001| ISI I.F.Value:1.241| Journal DOI: 10.36713/epra2016 ISSN: 2455-7838(Online) EPRA International Journal of Research and Development (IJRD)

- Vertical production chains;

- Aggregation of industrial entrepreneurs at a high level.

\section{DISCUSSION}

The review of theoretical works allowed us to conclude that one of the problems of practical use of the cluster concept is the lack of a unified approach to the conceptual apparatus, including the definition of a regional innovation cluster and types of innovative cluster effects.

Cluster effects are defined as the impact of participation in clusters on various output indicators of the firm and the cluster as a whole. In our study, we will focus on effects that describe the impact associated with cluster participation on the organization's performance, innovation activity, and competitiveness, i.e., innovative cluster effects $[5,6$, 7].

We have formulated a working definition of a regional innovation cluster based on the theory of industrial agglomeration, taking into account the peculiarities of cluster formation, as well as the innovative activity of participants: a group of enterprises of various types competing for products, factors of production and markets located on the territory of one region, and characterized by: increased innovation (new products, technologies, business processes) and close interaction with knowledge sources.

The analysis of theoretical and empirical research has allowed us to identify the following types of innovative cluster effects $[8,9,10,11,12$, 13]:

- effect of agglomeration. The benefits that firms derive from co-location within a specific territory include economies of scale, equalization of transport and logistics costs, reduction of barriers to the exchange of knowledge, ideas and management practices, and simplified access to unique assets.

- learning effect. Close cooperation, exchange of information and knowledge within the network of cluster participants (firms, research organizations, universities, and others), lead to an increase in the level of knowledge of all participants. In innovation clusters, continuous learning processes are enhanced, creating positive externalities in the management and technological spheres.

- effect of cooperative competition. In an economy characterized by extensive networks of enterprises working simultaneously in cooperation and competition with each other, there are areas where competing producers can cooperate. These include, for example, lobbying, trade shows and fairs, specialized investments in infrastructure and training.

In contrast to theory, in practice it is quite problematic to separate one effect from another - in developed innovation clusters; they may overlap and complement each other. The simultaneous influence of all components of innovative cluster effects leads to the emergence of synergy: firms participating in clusters are more motivated to create new products and firms than single enterprises, which leads to an increase in the innovative activity of all participants. Introduction of an approach to the study of regional innovation clusters that combines quantitative and qualitative analysis based on mezo-and micro-level.

When developing an approach, it is necessary to limit the scope of analysis of innovation clusters. First, we take into account innovation clusters where businesses may not have technological connections. Technologically linked chains are considered only as a part of an innovation cluster. Firms within the latter can use the full range of relationships: be members of the same business associations, collaborate with the same educational institutions, and demand the same innovative infrastructure. Secondly, the object of the study is not a single regional intersectoral innovation cluster with clearly defined borders, but a firm, and the probability of its participation in the cluster is estimated. We analyze enterprises that have a certain set of properties - location in the neighborhood, interaction with other market participants, innovation, which are more or less likely to be members of various innovation clusters in the region.

Our proposed 3-level approach can be presented as follows.

The first level is the study of conditions and opportunities for the formation of innovation clusters based on regional statistics. The study examines the regional environment, assesses the availability of competitive industries and necessary resources, the degree of diversification of the production structure, the degree of innovation activity of enterprises, and the infrastructure security of business in the broad sense of the word. If the results show that there are conditions for the development of clusters in the region, the next step is to search for those types of activities that have signs of clustering and the potential to increase innovation activity.

The second level is the identification of potential industry innovation clusters based on the assessment of localization and specialization coefficients that characterize the concentration of firms and employees in a particular sector of the region's economy. However, these indicators do not take into account cooperation between firms; they do not fully reflect the specifics of such a phenomenon as a cluster. Thus, for further analysis and evaluation of innovative cluster effects, it is necessary to move to the micro level, which allows not only to track the interaction within the cluster between organizations of various types of activities, but also to assess the factors that affect the probability of a firm's participation in clusters. 


\section{EPRA International Journal of Research and Development (IJRD)

The third level is a quantitative assessment of innovative cluster effects and qualitative characteristics of cooperation based on micro-level data. In this case, a combination of quantitative and qualitative analysis methods is used. At the first stage, using econometric modeling, the hypothesis is tested that enterprises get competitive advantages from the effects of close placement and interaction and competition, that is, from innovative cluster effects. This stage, in turn, is divided into three consecutive steps:

Step 1. Identification of participants in innovation clusters; effects;

Step 2. Assessment of the innovation cluster

Step 1. Identification of factors that affect the probability of entering of the firm into innovation clusters.

The goal of the second stage, based on the results of in - depth interviews with participants of innovation clusters, is to detect additional factors that cannot be identified during the statistical analyses. Thus, we include in the study those cluster agents with which the firm has no obvious technological connections.

Clusters have some key features. They cover the integration of scientific, educational and industrial potential of the region, has a high level of territorial concentration of cluster participants, which ensure the emergency of a synergistic effect in the modernization of industrial potential and innovative development of enterprises. In addition, clusters are characterized by the presence of systemically developing relationships and cooperation between cluster members. High innovative activity of cluster members allows us to constantly improve the competitive advantages of cluster members. Combining companies in clusters gives an advantage in reducing barriers to innovation, stimulating the development of the regional economy, improving the trade balance of the region, increasing employment and generally improving the competitiveness of the regional economy $[14,15]$.

Table 1

Types of cluster classification

\begin{tabular}{|c|c|}
\hline \\
\hline Classification parameters & Type of cluster \\
\hline By the type of dominant relationships & $\begin{array}{l}\text { horizontal, vertical; } \\
\text { industrial, spatial }\end{array}$ \\
\hline $\begin{array}{c}\text { According to the degree of specialization } \\
\text { /diversification }\end{array}$ & specialized, lateral, compositive, conglomerative \\
\hline $\begin{array}{l}\text { On the basis of availability of geographical } \\
\text { concentration }\end{array}$ & $\begin{array}{l}\text { urban, regional, national, cross-border; } \\
\text { virtual (spatial proximity is not required) }\end{array}$ \\
\hline By the source of induction & $\begin{array}{c}\text { artificially stimulated; } \\
\text { evolutionary (spontaneous) }\end{array}$ \\
\hline By level of industrial coverage & $\begin{array}{c}\text { micro-level (inter-company relationships); } \\
\text { mezo-level (separate industry and intersectoral relationships); } \\
\text { macro-level (considering the economy of the territory as a complex } \\
\text { of intersectoral relationships); }\end{array}$ \\
\hline By the nature of the main resource & $\begin{array}{c}\text { based on trade; } \\
\text { based on knowledge }\end{array}$ \\
\hline On the stage of the life cycle & $\begin{array}{l}\text { agglomeration; emerging; developing; } \\
\text { mature; transforming }\end{array}$ \\
\hline For the internal dynamics / efficiency & desirable; politically dependent; potential; latent; working \\
\hline By type of distribution of market power & asymmetric; symmetric \\
\hline By the nature of the participants & $\begin{array}{l}\text { clusters of small companies and clusters with the presence of large } \\
\text { businesses; } \\
\text { clusters of local companies and clusters involving third-party firms; } \\
\text { clusters of private companies; clusters with the presence of state } \\
\text { organizations }\end{array}$ \\
\hline By accessority & tradable; resource, local; high and low-income \\
\hline
\end{tabular}




\section{SJIF Impact Factor: 7.001| ISI I.F.Value:1.241| Journal DOI: 10.36713/epra2016 \\ ISSN: 2455-7838(Online) \\ EPRA International Journal of Research and Development (IJRD)

An important feature of a cluster that distinguishes it from other forms of business coordination is its location on a compact territory, which leads to an agglomeration effect. Production integration, supplemented by territorial proximity of enterprises and organizations participating in the cluster, generate a coordination mechanism for joint action that contributes to positive external effects from the close proximity of a large number of firms specializing in a particular field, closely connected through business and personal contacts to create opportunities for flexible response to changing consumer demands, to create conditions for the integration of institutions of higher education, business and science.

The economic effect of clusters is to increase labor productivity, reduce production costs, facilitate access to a new market, stimulate new companies, develop innovative potential, etc.

Regional industrial clusters are characterized by a high degree of implementation of innovative resources by reducing operating costs and transport costs of cluster participants due to the concentration of the industry enterprise in one territory. Minimizing investment risks by distributing them among cluster members also contributes to this process. In this regard, clusters stimulate innovation through the exchange of know-how, qualified personnel, and interaction with educational institutions. In addition, clustering contributes to the commercialization of knowledge by stimulating the creation of new companies, the ability to quickly test innovative products and services on the market.

One of the main features of the cluster is the presence of a set of associated positive effects that form their comparative advantages, such as the production scale effect, the coverage effect, the synergy effect and the multiplier effect [16].

The basis of the production scale effect is the presence of a core of innovation activity in the face of one of the cluster firms.

The optimal combination of elements of the cluster system creates a synergy effect, which increases the quality of products and improves the efficiency of interaction between the successful clusters. The essence of the effect is that a new economic structure that appears when merging enterprises can use a synergistic effect, while the result of such an Association exceeds the sum of the results of the activities of separate enterprises. However, here each participant retains its independence and fights to increase its own competitive advantages within the cluster, which generally contributes to the elimination of inefficient forms of enterprises.

With the simultaneous effect of scale, coverage and synergy, non-profit cluster members can overcome the lower margin of profitability with the help of specialization, which provides increased productivity and reduced cost of production. This way, businesses that are part of the cluster get additional competitive opportunities.

The multiplicative effect of a cluster is influenced not only by the economic, but also by the geographical location of the region, which determines the degree of its economic isolation or openness, as well as the development and stability of the regional economy, which is largely provided by successfully functioning regional clusters. The ability of regional enterprises to produce competitive products that are in high demand not only in the region itself, but also outside it, determines a fairly high level of the multiplier effect.

In addition to the multiplier effect for cluster members, the multiplier effect also occurs for enterprises in related industries and supporting industries that form the cluster infrastructure. This is primarily due to the territorial proximity of enterprises to key cluster participants, the growth of investment attractiveness of the cluster, and the activation of innovation processes. Thus, attracting investment to clusters contributes to the emergence of a multiplicative effect of economic development in the entire region.

\section{CONCLUSIONS}

Along with the activation of innovation processes in the region, clustering of the region's industry creates additional opportunities for sustainable development of the region. This will be due to the following circumstances:

1. Clusters, acting as an important factor in the formation and dissemination of industrial knowledge and skills through joint exchange of experience and joint training, contribute to the formation of sustainable innovation in the "learning region". The formation and use of industrial knowledge, skills and innovations are the most important factors of the region's competitiveness in the context of a globalized economy and the transition of the country's economy to a knowledgebased economy.

Cluster members take benefit from technology exchanges with large foreign corporations and local industrial equipment suppliers by reducing transaction costs, providing a high degree of flexibility in technology transfer, and effectively controlling the results of operations. In addition, many large foreign companies prefer faceto-face contact with local businesses, as technology exchange is a matter of trust. 


\section{SJIF Impact Factor: 7.001| ISI I.F.Value:1.241| Journal DOI: 10.36713/epra2016 ISSN: 2455-7838(Online) EPRA International Journal of Research and Development (IJRD)

The role of social relations in the region is also important for the formation of industrial knowledge. These social interactions arise from the historical and cultural characteristics of the region, which include: common standards and values, forms of interaction between subjects, specific forms of innovation within the cluster, and trust. Therefore, at the regional level, clusters provide a wide range of positive externalities or an innovative push, through the use of the region's available resources, its educational and research potential, and the cluster's communication network.

2. Clusters create conditions for accelerated modernization of local small enterprises. One of the main goals of sustainable regional development is to find reserves for growth of gross value added in the region. In recent decades, integration into the global production network has been a factor in increasing value added. The modernization of local small and medium-sized enterprises implies a process by which economic entities move from low-profit to relatively high-profit activities.

Regional industrial clusters provide small firms with a high degree of specialization in servicing specific industrial segments, as this facilitates access to the capital of an industrial enterprise, as well as an active exchange of ideas and transfer of knowledge from specialists to entrepreneurs starting their own business.

Modernization will mainly be achieved by improving the economic performance of small enterprises, updating production processes, improving product quality, switching to more profitable activities in the value chain, as well as innovation, technology, design and marketing.

Modernization in creating a value chain in production networks has a positive impact. However, such an upgrade always leads to wins and losses among companies and employees, and the profit generated from the increase in value through the upgrade processes is often distributed very unevenly. In addition, such benefits are not provided to the firm's employees in the form of higher wages, greater job security, or improved working conditions.

Modernization of small enterprises allows the implementation of a long-term development strategy, increased tax payments, environmental protection, health and safety of the region's population. This concept takes into account various forms of social modernization and environmental improvement, as well as the economic modernization of local small enterprises.

3. Clustering of the region's industry allows regional authorities to move from supporting specific enterprises to providing systematic support to target groups. Systematic support of target groups gives a multiplier effect to the development of the regional economy, which provides a qualitative leap in the innovative development of the region. State support for cluster enterprises also reduces barriers to innovation, encourages the development of the regional economy, improves the trade balance of the region, promotes the use of various sources of technological knowledge and connections, and increases the competitiveness of the regional economy or the country as a whole.

4. Clustering improves the exchange of information between potential cluster participants. The cluster formation process is based on the exchange of information about needs, equipment and technology between industries - buyers, suppliers and related industries. Territorial innovation and industrial clusters are based on a stable system of dissemination of new technologies, knowledge, products, the so-called technological network, which is based on a joint scientific base. The latter are focused on the exchange of strategic know-how and achievements of long-term partnership agreements. Continuous interaction facilitates formal and informal exchange of information about the prospects for cooperation between organizations with complementary assets and professional skills. The exchange of information, production experiences, and $\mathrm{R} \& \mathrm{D}$ results leads to the improvement of educational and scientific institutions and the creation of a developed social and cultural capital. As a result, the region of the country becomes an attractive center for foreign investment, which in turn accelerates the economic development of the country as a whole.

5. Clusters are a great importance for improving the competitiveness of an economic region. The competitiveness of enterprises in clusters leads to an increase in the competitiveness of the industry and the country's regions as a whole. Clustering increases the scale of activities, increases the demand for factors of production, including labor, and stimulates the growth of exports outside the region and the flow of financial resources. Competitive clusters have a large contribution to the value chain. They create a synergy effect based not so much on tangible, but rather on intangible assets, which are characterized by the creation of high added value.

6. Clusterization affects the growth of wages and living standards of the population. The expansion of the cluster is due to the acceleration of research and innovation activities in the region and the formation of a highly qualified workforce. Improving the skills of employees in the cluster guarantees higher wages for work due to increased productivity in the activities of firms in clusters and increased cash flows from outside. The increase in wages, in turn, affects the income of the population and the well-being of the region's labor resources. As a result, the region becomes an attractive center for specialists and workers from other regions. By providing high employment in the region, clusters contribute to the development of local infrastructure and improve the 


\section{SJIF Impact Factor: 7.001| ISI I.F.Value:1.241| Journal DOI: 10.36713/epra2016 \\ ISSN: 2455-7838(Online) \\ EPRA International Journal of Research and Development (IJRD)

living conditions of the region's population.

7. Clustering contributes to business development and the formation of new forms of entrepreneurship in the region. With the development of the cluster, create conditions for the specialization of labor resources and improvement of the business environment of the region.

8. Clustering contributes to the inflow of foreign investment in the region. Along with other factors, clusters play an important role in shaping the country's investment climate. As the formation of clusters in the regions enhances competitiveness not only of enterprises participating in the cluster, but also the economy of the region as a whole, which positively affects many aspects of life of the region and its population, socio-economic indicators. The formation and development of clusters contributes to the stabilization of the labor market, reducing the personnel deficit of enterprises, reorienting unprofitable enterprises and, ultimately, leads to an increase in investment activity. Creating conditions for accelerated business development and increasing the competitiveness of their constituent companies, clusters are more attractive centers for foreign investment. Investing in an enterprise network within a cluster that has a developed infrastructure with extensive interaction with educational and research organizations is characterized by relatively low risk and high returns. The inflow of foreign investment, in turn, can turn the region into a point of economic growth, which improves the image of the region before domestic and foreign investors. Active investment activity contributes to the diversification of the structure of the regional economy, increases its socio-economic indicators and creates additional jobs.

Thus, the positive effect of clustering industry in the region covers broad aspects of regional development. By intensifying research and accelerating innovation, clusters ensure the economic development of the most important sectors of the region's economy and increase the innovative potential of enterprises and stimulate intra-firm competition, strengthen the desire of entrepreneurs to innovate and modernize the production structure. All this contributes to progress in the regions and in the country as a whole.

The cluster approach contributes to the formation of newly created territorial production complexes in the region due to the high competitive advantage of such complexes, both on the global and national markets. By connecting the center and the environment through closer inter-firm interaction, regional clusters form common labor markets, facilitate the movement of technologies, and increase the availability of shared resources for enterprises. Due to the impact of scale effects and synergy, all cluster participants gain additional competitive advantages through the development of horizontal network cooperative relations, as well as partnership between business, government, science and education. The synergetic effect of clusterization of the economy is expressed in the form of additional added value due to the effective interaction of economic entities, which is an integral element of the economic space of the cluster.

Considering the key advantages of clusters in the regional economy, it is necessary to say that the development of integration relations between industry enterprises gives a serious boost to the prosperity of the region's economy and the elimination of inefficient production structures operating in the region. Especially, effective interaction of government bodies with business solves problems related to the development of public-private partnership in the economy. In the future, the regions where clusters are formed will become the leaders of the country's economy and determine the competitiveness of the national economy. In addition, clusters contribute to regional and national development based on innovative technologies, which indicates the importance of the cluster for the sustainable development of the region.

\section{LITERATURE}

1. Гуриева Л.К. Синергетические эффекты кластерной организации промышленных предприятий // УЭкC, 2013. - №12 (60). URL: https://cyberleninka.ru/article $/ \mathrm{n} /$ sinerge ticheskie-effekty-klasternoy-organizatsiipromyshlennyh-predpriyatiy (дата обращения: 06. 10. 2018).

2. Портер М. Конкуренция. - М.: Изд. Дом «Вильямс», 2003. - С.376.

3. Беспалов М.В. Роль и значение инновационных кластеров в осуществлении национальных $и$ региональных инновационных программ развития//Качество. Инновачии. Образование. - М.: ПК «СТС-Принт», 2009. №2. - C.23-27.

4. Куркудинов Е. В. Кластерный подход как технология управления экономическим развитием региона. [Электронный ресурс], Режим docmyna: ecsocman. hse. ru> data/2011/03/22/1268220201/35.pdf.

5. Ханкелдиева Г.Ш. Особенности корпоративного управления в акционерных обществах с государственным участием // Бюллетень науки и практики. Электрон. журн. 2017. №11 (24). С. 357-363. Режим доступа:

http://www.bulletennauki.com/honkeldiyeva

6. Ханкелдиева Г. Ш. Перспективы развития электроэнергетической отрасли Республики Узбекистан в условиях модернизации экономических отночений // Бюллетень науки и практики. Электрон. журн. 2017. №12 (25). C. 293-299. Режим доступа: http://www.bulletennauki.com/honkeldiyeva-g (дата обращения 15.12.2017). 


\section{EPRA International Journal of Research and Development (IJRD) \\ Volume: 5 | Issue: 7 | July 2020

7. Khankeldieva G.Sh. Prospects of the development of of investment activity in the field of tourist services: problems and ways of solution. // International Scientific Journal "Theoretical \& Applied Science", Philadelphia, USA. 10, (78), 2019. - 160-165 pp.

8. Мирзаев А.T. Оиенка использования рекреационных возможностей на рынке туристических услуг // Региональная экономика: теория и практика. - 2019. - T. 17, № 5. - C. 990 - 1002. https://doi.org/10.24891/re. 17.5 .990

9. Mirzaev, A. T. (2020). Assessment of cluster formation in management of recreational activity. ISJ Theoretical \& Applied Science, 04 (84), 605-610. https://dx.doi.org/10.15863/TAS.2020.04.84.101

10. Mirzaev, A.T (2018) "The level of use of tourist attractions in the regions and the factors affecting them," Economics and Innovative Technologies: Vol. 2018: No.3,Article19.Available at: https://uzjournals.edu.uz/iqtisodiyot/ vol2018/iss $3 / 19$

11. Мирзаев, A. T. (2019). Совершенствование интегральной оиенки механизма рекреационно-туристических объектов. Бюллетень науки и практики, 5(2). - C. 127-134. https://doi.org/10.33619/24142948/39/17

12. Mirzaev A. T. Estimation of the prospects for the use of recreational facilities in the market of tourism services //Наука сегодня: вызовы, перспективы и возможности [Текст]. - 2018. - C. 76.

13. Mirzaev A. T. Evaluation of innovation capacity resource components in effective management of recreational clusters on the basis of econometric analysis // EPRA International Journal of Research and Development (IJRD). - 2020 .pp.131-137. https://doi.org/10.36713/epra4790

14. Асракулов, А. С. (2019). Неформальная занятость и анализ факторов, влияющих на неформальную занятость в Узбекистане. Региональная экономика: теория и практика, 17(12), 2328-2336. https://elibrary.ru/item.asp?id=41473273

15. Asrakulov, A. S. (2017). Some aspects of development of the labor market of the Republic of Uzbekistan. Актуальные проблемь сочиально-гуманитарных наук (рр. 39-42).

16. Орипов A. A. (2019) Развитие информачионно-коммуникационных технологий в Узбекистане. Образование и наука в России и за рубежсм, (16). 